\title{
Origami Game for Improving Fine Motor Skills for Children 4-5 Years Old in Gang Buaya Village in Salatiga
}

\author{
Steffi Claudia $^{1 \bowtie}$, Ajeng Ayu Widiastuti $^{2}$, Mozes Kurniawan ${ }^{3}$ \\ PG PAUD, FKIP,Universitas Kristen Satya Wacana
}

\begin{abstract}
The purpose of this study was to improve the fine motor skills of 4-5-year-old children through origami games in Kampung Gang Buaya Salatiga. Attractive origami paper folding activities can motivate children to improve their fine motor skills. This type of research is Participatory Action Research (PAR) conducted through 2 cycles. The research subjects were SI 5 girls and 4 boys. Data collection techniques use interviews and documentation. The research object is children's fine motor skills through origami paper games. Data Analysis Techniques using Quantitative Descriptive. Branch stitching can be seen from the average fine motor skills of children with origami paper applications with the criteria of Developing According to Hope that is $76 \%$. The results of this study indicate an increase in children's fine motor skills through playing origami paper in the village of Gang Buaya Salatiga, which is seen from the children's fine motor skills in the pre-action stage, which is an average of $33.3 \%$ to $65.38 \%$ in cycle I actions, then increased to $79.62 \%$ in the transition period II.
\end{abstract}

Keywords: Fine Motor, The game of Origami Paper

\begin{abstract}
Abstrak
Tujuan penelitian ini ialah meningkatkan motorik halus anak usia 4-5 tahun melalui permainan origami di Kampung Gang Buaya Salatiga. Kegiatan melipat kertas origami yang menarik dapat memotivasi anak untuk meningkatkan motorik halusnya. Jenis penelitian ini adalah Participatory Action Research (PAR) yang dilakukan melalui 2 siklus. Subyek penelitian berjumlah 5 anak perempuan dan 4 anak laki-laki. Teknik Pengumpulan Data menggunakan wawancara, observasi dan dokumentasi. Obyek Penelitian ialah kemampuan motorik halus anak melalui permainan kertas origami. Teknik Analisis Data menggunakan Deskriptif Kuantitatif. Indikator keberhasilandilihat dari rata-rata kemampuan motorik halus anak dengan permainan kertas origami dengan kriteria Berkembang Sesuai Harapan yaitu $76 \%$. Hasil penelitian ini menunjukkan adanya peningkatan kemampuan motorik halus anak melalui permainan kertas origami di kampung Gang Buaya Salatiga, yang dilihat darimeningkatnya kemampuan motorik halus anak pada tahap pratindakan yaitu rata-rata 33,3 $\%$ menjadi $65,38 \%$ pada tindakan siklus I, lalu meningkat menjadi $79,62 \%$ dalam tahap siklus II.
\end{abstract}

Kata Kunci:Motorik Halus , Permainan Kertas Origami

@ Jurnal Obsesi Prodi PG-PAUD FIP UPTT 2018

$\triangle$ Corresponding author:

Address : Salatiga, Jawa Tengah, Indonesia

ISSN 2356-1327 (Media Cetak)

Email : 272014008@student.uksw.edu

ISSN 2549-8959 (Media Online) 


\section{PENDAHULUAN}

Pendidikan Anak Usia Dini (PAUD) adalah tahap dalam pendidikan sebagai proses yang sediakan untukanak usia 0 sampai dengan usia 6 tahun dengan cara memberikan stimulasi yang berguna membantu tumbuh kembang anak supaya anak siap untuk melangkah ke pendidikan selanjutnya. Salah satu perkembangan anak usia dini yaitu pada aspek motorik. Motorik anak di bedakan menjadi dua yaitu, motorik kasar dan motorik halus. Motorik kasar ialah kegiatan yang melibatkan otot-otot besar dengan aktivitas menggunakan anggota seluruh tubuh, contoh berlari, melompat. Atik Mulyati,(2014)mengatakan motorik halus ialah kegiatan dengan melibatkan otot-otot kecil, aktivitas yang dapat diajarkan secara bertahap sehingga dapat di mengerti anak. Kegiatan motorik yang sering dilakukan dapat membantu anak meningkatkan koordinasi jari secara bertahap.

Selain itu, kegiatan melipat origami juga membantu dalam mempersiapkan keterampilan menulis dan menggambar pada anak usia dini, Melipat origami dapat meningkatkan perkembangan motorik halus pada anak, dengan mengikuti arahan lipatan sesuai bentuk yang dibuat, dengan permainan kertas origami, dapat melatih jari-jemari anak. Dalam Permendikbud 137 Tahun 2014, menuliskan tentang kemampuan motorik halus anak usia 4-5 tahun seperti anak mampu membuat garis vertikal, horizontal, lengkung kiri/kanan, miring kiri/kanan, dan lingkaran, menjiplak bentuk, mengkoordinasikan mata dan tangan untuk melakukan gerakan yang rumit, namun hal ini berbeda dengan kondisi anak-anak di kampung Gang Buaya.

Mengetahui betapa pentingnya meningkatkan kemampuan motorik halus pada anak usia dini yang berada pada rentang usia 4-5 tahun, penulis memiliki ketertarikan dan keinginan untuk mengkaji lebih dalam lagi tentang kemampuan motorik halus pada anak usia dini di Dusun Blotongan Salatiga. Setelah melakukan observasi penulis melihat bahwa anak usia 4-5 tahun di Dusun Blotongan, perkembangan motorik halus anak masih belum optimal. Anak masih kesulitan saat memegang sendok dengan jari tangan, gunting dan pensil. Kurangnya kemampuan anak dalam kemampuan motorik halus diduga diakibatkan dari kurangya pendampingan orang tua kepada anak-anaknya karena kesibukan orang tua yang begitu menyita waktu pendampingan dan pengajaran di lingkungan rumah tangga.

Dari hasil wawancara dengan orang tua mengatakan bahwa jarang mengenalkan permainan origami kepada anaknya. Alasan dari Orang tua adalah orang tua sibuk bekerja sehingga tidak ada waktu untuk anaknya.Untuk itu peneliti tertarik untuk membantu meningkatkan kemampuan motoric halus, kemampuan ini dapat ditingkatkan dengan cara yang tepat yakni dilakukan dengan bermain yang merupakan kegiatan yang menyenangkan bagi anak sehingga mereka merasa tidak bosan. Permainan Origami dipilih dengan alasan bahwa media ini belum pernah digunakan orang tua dalam mengajarkan motorik halus kepada anaknya. Berdasarkan observasi penulis, anak-anak usia 4-5 tahun belum memiliki kegiatan belajar yang dikemas dan disajikan dalam bentuk media gambar. Selain itu, permainan origami yang dijadikan sebagai salah satu alternative dalam upaya meningkatkan kemampuan motorik halus anak. Hal tersebut didasari oleh penelitian terdahulu yang menyatakan bahwa kemampuan motoric halus yang digunakan melalui permainan origami dapat meningkat.

\section{Pengertian Motorik Halus}

Menurut Jumiarsih.C (2012) Motorik Halus anak adalah kesanggupan dalam suatu bidang tertentu yang berhubungan dengan gerakan yang melibatkan bagianbagian tubuh tertentu saja dan dilakukan oleh otot-otot kecil seperti ketrampilan menggunakan jari-jari tangan dan gerakan pergelangan tangan, sedangkan menurut

Sunani (2016) Motorik Halus merupakan aktivitas dengan melibatkan otot-otot kecil, seperti keterampilan 
menggunakan jari-jemari dan menggunakan pergelangan tangan yang tepat.Santrock (2007) menyatakan bahwa motorik halus adalah keterampilan menggunakan media dengan koordinasi antara mata dan tangan, sehingga gerakan tangan perlu dikembangkan dengan baik agar keterampilan dasar yang meliputi membuat garis horizontal, garis vertikal, garis miring ke kiri atau miring ke kanan, lengkung atau lingkaran dapat terus ditingkatkan.

Dari beberapa pendapat diatas, dapat disimpulkan bahwa motorik halus merupakan keterampilan yang menggunakan jari-jari tangan dan gerakan pergelangan tangan yang membutukan koordinasi mata dan tangan guna menghasilkan sebuah media atau keterampilan lainnya.

\section{Tujuan dan Fungsi Motorik Halus}

Sunani (2016), menjelaskan tujuan dari keterampilan motorik halus yaitu: a. Mampu memfungsikan otot-otot kecil seperti gerakan jari tangan. b. Mampu mengkoordinasikan kecepatan tangan dan mata. c. Mampu mengendalikan emosi.

Santrock (2007) mengemukakan bahwa fungsi-fungsi perkembangan motorik halus adalah sebagai berikut: (a) Keterampilan untuk membantu diri sendiri; (b) Keterampilan bantu sosial; (c) Keterampilan bermain; dan Keterampilan sekolah.

Ningsih. A (2015) mengemukakan tentang fungsi keterampilan motorik halus yaitu sebagai berikut: (a) Melatih kelenturan otot jari tangan; (b) Memacu pertumbuhan dan perkembangan motorik halus dan rohani; (c) Meningkatkan perkembangan emosi anak; (d) Meningkatkan perkembangan sosial anak; dan (e) Menumbuhkan perasaan menyayangi terhadap diri sendiri.

Dari beberapa pendapat diatas, tujuan dan fungsi motorik halus yaitu yang mengatakan bahwa aktivitas motorik anak usia Taman Kanak-Kanak bertujuan untuk melatih kemampuan koordinasi motorik anak.

\section{Pengertian Origami}

Origami ialah kegiatan melipat kertas yang berasal dari Jepang. Istilahorigami terbagi menjadi dua kata oru dan kami. Oru berati melipat dan kami berati kertas. Elfianingrum (2010) mengatakan kegiatan melipat adalah aktivitas yang menggunakan keterampilan tangan guna menghasilkan suatu bentuk tanpa menggunakan perekat (lem). Aktivitas ini diperlukan kerjasama antara mata dan tangan, ketelitian, kesabaran. Penggunaan kertas origai yang berbentuk segi empat , berguna untuk melipat 1-6 lipatan, membuat bentuk anjing, kipas, bentuk amplop.

Tujuan dari kegiatan melipat secara khusus ialah dapat meningkatkan imajinasi anak, daya ingat anak dapat di tingkatkan, kesabaran dan ketelitian bagi anak, melatih kerapian dalam melipat, ketelitian dalam melipat dapat di tingkatkan. Menurut pernyataan diatas yaitu dengan menggunakan origami, dapat meningkatkan kemampuan anak dalam hal kesabaran, ketelitian, ataupun dapat mengembangkan imajinasi anak dalam hal melipat bentuk origami. Melalui penelitian inidiharapkan anak dapat menguasai 1-6 lipatan pada kertas origami sesuai dengan bentuk, dimulai dari bentuk termudah hingga yang rumit. Penilitian ini juga bertujuan agar anak mampu meningkatkan koordinasi mata dan tangan secara mandiri..

\section{METODE}

Jenis penelitian ini menggunakan jenis penelitian Partisipatory Action Research (PAR). Menurut Mikkelsen.B (2003) PAR yaitu penelitian yang melibatkan beberapa orang dalam penelitian guna untuk mengubah dan memperbaiki. Waktu Penelitian dilakukan selama bulan Januari 2018 hingga April 2018.

Subyek Penelitian Subyek dalam penelitian ialah anak dengan umur 4-5 tahun di Kampung Gang Buaya Salatiga dengan berjumlah 9 anak, diantaranya 5 laki-laki dan 4 perempuan.Indikator Kinerja Keberhasilan kegiatan penelitian 
146 | Origami Game for Improving Fine Motor Skills for Children 4-5 Years Old

ini akan terlihat dengan adanya peningkatan yang signifikan terhadap kemampuan motorik halus anak, yaitu : menirukan melipat kertas sederhana (1-6 lipatan), menggunting zig zag.

Metode pengumpulan data pada penelitian ini sebagai berikut: Wawancara, Observasi, Dokumentasi, dan Catatan Lapangan..

\section{HASIL DAN PEMBAHASAN Kondisi Awal Penelitian}

Kondisi awal penelitian merupakan gambaran awal untuk anak mampu mengembangkan motorik halusnya melalui kegiatan menggunting mengikuti garis. Hasil penilaian dilakukan melalui observasi berdasarkan indikator tingkat pencapaian motorik anak. Berikut ini rekapitulasi data anak pada saat melalukan pra tindakan.

Tabel 2 Hasil Pra penelitian

\begin{tabular}{||c|c|c|}
\hline \multicolumn{3}{|c|}{ Pra Penelitian } \\
\hline Kriteria & Melipat & $\%$ \\
\hline BB & 2 & 22 \\
\hline MB & 7 & 78 \\
\hline BSH & 0 & 0 \\
\hline BSB & 0 & 0 \\
\hline Jumlah & 9 & 100 \\
\hline
\end{tabular}

Dari kegiatan Pra Tindakan, anakanak diajak untuk melalukan kegiatan melipat dasar, seperti melipat dengan arah diagonal, arah horizontal. Dari tabel diatas dapat dijelaskan bahwa dalam kriteria Belum Berkembang terdapat 2 anak dengan presentase $(22,2 \%)$, dalam tahap ini anak belum dapat melakukan instruksi dalam melipat, dalam kriteria Mulai Berkembang terdapat 7 anak dengan presentasi $77,8 \%$ ). Pada penelitian pra tindakan melipat mendapat rata-rata 34,25 $\%$ sehingga diputuskan untuk melakukan penelitian.

\section{Siklus I}

Dalam tahap perencanaan, peneliti membuat RKH(Rancangan Kegiatan Harian), kemudian dilanjutkan untuk penelitian, dalam 1 siklus terdapat 3 kali pertemuan, peneliti dibantu oleh guru ngaji dalam proses observasi, pengambilan data dan refleksi. Berikut ini adalah hasil Siklus 1 pertemuan I hasil perolehan ratarata 49, 93\% dengan penilaian Mulai Berkembang. Untuk pertemuan II, diperoleh rata-rata $51,81 \%$ dalam pertemuan kedua ini anak mengalami peningkatan, sehingga mendapat kriteria Berkembang Sesuai Harapan. Untuk pertemuan yang III hasil diperoleh dengan rata-rata $65,73 \%$, dalam pertemuan ketiga ini, anak mengalami peningkatan dalam melipat origami, terlihat dengan hasil sebelumnya rata-rata yang diperoleh 51,81 sehingga sekarang rata-rata menjadi 65,38 $\%$.

Tabel 3 Hasil penelitian siklus 1 sampai siklus III

\begin{tabular}{||c|c|c|c|}
\hline \multicolumn{2}{||c|}{$\begin{array}{c}\text { Siklus I Pertemuan } \\
\text { I }\end{array}$} & $\begin{array}{c}\text { Siklus I } \\
\text { Pertemuan } \\
\text { II }\end{array}$ & $\begin{array}{c}\text { Siklus I } \\
\text { Pertemuan } \\
\text { III }\end{array}$ \\
\hline Kriteria & $\begin{array}{c}\text { Jumlah } \\
\text { Anak }\end{array}$ & $\begin{array}{c}\text { Jumlah } \\
\text { Anak }\end{array}$ & $\begin{array}{c}\text { Jumlah } \\
\text { Anak }\end{array}$ \\
\hline BB & 1 & 0 & 0 \\
\hline MB & 7 & 5 & 2 \\
\hline BSH & 1 & 4 & 7 \\
\hline BSB & 0 & 0 & 0 \\
\hline Jumlah & 9 & 9 & 9 \\
\hline
\end{tabular}

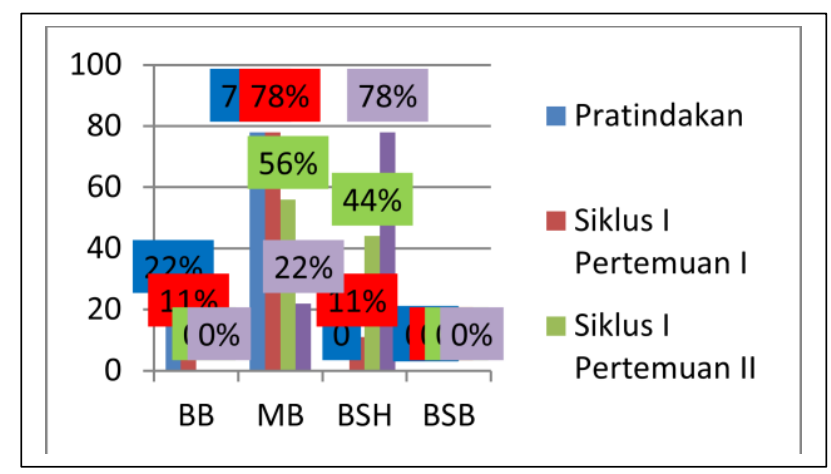

Gambar 1. Penyajian data dari Pratindakan sampai Siklus I Pertemuan III

\section{Tindakan Siklus II}

Dalam tahap perencanaan, peneliti membuat RKH(Rancangan Kegiatan Harian) dengan berbeda-beda tema kegiatan, kemudian dilanjutkan untuk obsservasi, dalam 1 siklus terdapat 2 kali 
pertemuan, peneliti dibantu oleh guru ngaji dalam proses observasi dan pengambilan nilai, di tahap akhir refleksi. Berikut ini adalah hasil Siklus II.

Tabel 4. Perbandingan Siklus II Pertemuan I dan II

\begin{tabular}{|c|c|c|c|c|}
\hline \multicolumn{2}{|c|}{ Siklus II Pertemuan I } & \multicolumn{2}{c|}{$\begin{array}{c}\text { Siklus II } \\
\text { Pertemuan II }\end{array}$} \\
\hline Kriteria & $\begin{array}{c}\text { Jumlah } \\
\text { Anak }\end{array}$ & $\begin{array}{c}\text { Perse } \\
\text { ntase }\end{array}$ & Jumlah & $\begin{array}{c}\text { Present } \\
\text { ase }\end{array}$ \\
\hline BB & 0 & 0 & 0 & 0 \\
\hline MB & 1 & $11 \%$ & 0 & 0 \\
\hline BSH & 6 & $67 \%$ & 5 & $56 \%$ \\
\hline BSB & 2 & $22 \%$ & 4 & $44 \%$ \\
\hline Jumlah & 9 & 100 & 9 & 100 \\
\hline \multicolumn{7}{|l|}{} \\
\hline
\end{tabular}

Setelah dilaksanakannya pertemuan II terjadi peningkatan dimana anak dengan kriteria BSHberjumlah 5 orang presentase $56 \%$ untuk kriteria BSB (Berkembang Sangat Baik ) berjumlah 4 anak presentase presentase $44 \%$. Data yang diperoleh dari siklus II pertemuan II mendapat rata-rata $79,93 \%$.

Meningkatnya motorik halus anak bisa dilihat melalui tabel yang diperoleh pada Siklus II dari pertemuan pertama, kedua. Dikarenakan pada siklus II sudah mecapai indikator yang sudah di tetapkan, yakni $76 \%$ maka diputuskan untuk tidak perlu dilanjutkan lagi dan cukup pada siklus. Dari data diatas dapat di kemukakan bahwa dengan permainan origami kemampuan motorik halus anak usia 4-5 tahun dapat meningkat hingga $79,93 \%$. Kondisi awal kemampuan motorik halus anak dilihat dari prapenelitian $22 \%$ kemampuan motorik halus anak dalam kriteria belum berkembang, $78 \%$ dalam kriteria mulai berkembang dengan ini dilaksanakannya penelitian dengan menggunakan permainan origami.

Dalam siklus I terdapat 3 pertemuan diantaranya pertemuan pertama, di peroleh $49,93 \%$, siklus I pertemuan II diperoleh $51,81 \%$, siklus I Pertemuan III di peroleh $65,75 \%$. Dalam siklus I menggunakan metode demontrasi, dimana peneliti menjelaskan beberapa contoh bentukbentuk lipatan, namun dalam siklus I ini terdapat beberapa kendala diantaranya anak kurang begitu menarik dengan kertas yang digunakan seingga anak lebih tertarik untuk mengobrol dengan yang lain.

Dalam siklus II terdapat II pertemuan, untuk pertemuan I di peroleh $68,50 \%$, untuk pertemuan II diperoleh $79,62 \%$. Dalam penelitian ini, peneliti memberikankegiatan melipat kepada anak dari melipat yang mudah sampai pada tahap melipat secara mandiri.

Dalam penelitian ini juga memberikan contoh dalam melipat yang benarsehingga dengan melakukan kegiatan melipat ini, anak mendapat manfaat dari kegiatan melipat ini salah satunya dengan melipat anak bisa melatih konsentrasinya seperti yang diungkapkan oleh Atik Mulyati, (2014) manfaat dari origamiialah Anak dapat belajar meniru/mengikuti arahan, ketika anak mendengarkan dan mengikuti arahan secara bertahap, secara tidak langsung anak mengikuti arahanarahan yang di berikan oleh guru ataupun pendidik, sehingga anak dapat belajar mengikuti arahan maupun meniru.Dalam pra tindakan

\section{SIMPULAN}

PAR (Partisipatory Action Reseach) yang dilakukan di Kampung Gang Buaya , Blotongan Salatiga melalui permainan origami untuk meningkatkan motorik halus anak usia 4-5 tahun. Melalui permainan origami, motorik halus anak dapat meningkat secara bertahap. Halini di dapat di buktikan dari hasil tindakan penelitian yang dilakukan.

Berdasarkan hasil penelitian dapat disimpulkan bahwa permainan Origami dapat meningkatkan motorik halus anak , hal ini bisa dibuktikan dari meningkatnya persentase motorik halus anak. Ketrampilan motorik halus anak meningkat pada Siklus I sebesar 49, 93\% menjadi $51,81 \%$. Pelaksanaan Siklus II mengalami peningkatan sebesar 68,50\% menjadi 79 . $62 \%$.

Dengan demikian, dapat disimpulkan bahwa dengan melalui permainan origami dapat meningkatkan keterampilan motorik halus anak usia 4-5 tahun, juga dengan 
permainan kertas origami dapat melatih koordinasi mata dan tangan.

\section{UCAPAN TERIMA KASIH}

Penulis ucapkan terima kasih kepada segenap pimpinan dan civitas akademika Universitas Kristen Satya Wacana Salatiga Jawa barat memberikan dukungan dalam penulisan artikel ini. Orang tua dan kawankawan seperjuangan penulis serta Pihak sekolah tempat penulis melakukan penelitian. Reviewer dan editor Jurnal Obsesi yang telah memberikan masukan kepada penulis dalam menulis artikel ini.

\section{DAFTAR PUSTAKA}

Arikunto. S (2013). Prosedur Penelitian Suatu Pendekatan Praktik. Jakarta. Rineka Cipta

Atik Mulyati. (2014) Meningkatan Keterampilan Motorik Halus Melalui Origami Pada Anak Kelompok A Tk Kusuma Baciro Gondokusuman Yogyakarta. Skripsi (Diterbitkan). Fakultas Ilmu Pendidikan Universitas Negeri Yogyakarta. http://eprints.uny.ac.id/13016/1/skri psi_atik\%20mulyati_nim.12111247 007.pdf. Diakses pada 26 Juli 2017 pukul 12.37

Chraig Mertler, A. (2011). Action Research.Yogyakarta: Pustaka Pelajar

Efianingrum.A (2010) Pengertian Seni Origami. Diakses pada tanggal 17 Juli 2017 pada pukul20.00.http://staff.uny.ac.id/site s/default/files/penelitian/Ariefa\%20 Efiangrum,\%20M.Si./Artikel\%20JK \%20UNY\%202010.pdf

Jumiarsih. C (2012). Upaya Meningkatkan Kemampuan Motorik Halus Anak Melalui Kegiatan Melipat Pada Anak Kelompok A Di TK Aisyiyah 2 Pandeyan Ngemplak Boyolali Tahun Ajaran 2012/2013. http://eprints.ums.ac.id/20921/18/N ASKAH_PUBLIKASI.pdf. Diakses pada 20 Juli 2017 pukul 16.00.

Mikkelsen.B (2003). Metode Penelitian Partisipatoris Dan Upaya-Upaya
Pemberdayaan Sebuah Buku

Pegangan Bagi Praktisi Lapangan,

Jakarta : Yayasan Obor Indonesia

Ningsih. A. (2015). Identifikasi

Perkembangan Keterampilan

Motorik HalusAnak Dalam

Berbagai Kegiatan Main Di

Kelompok BTk Se-Gugus Parkit

Banyuurip Purworejo. Di akses pada

17 Januari 2018 pukul 13.00

Peraturan Menteri Pendidikan Dan Kebudayaan Republik Indonesia Nomor 137 Tahun 2014 tentang Tingkat Pencapaian Pekembangan Anak Lingkup Perkembangan Motorik Halus anak 4-5 tahun

Sunani. (2016). Pengembangan Kemampuan Moorik Halus Anak Melalui Permainan Melipat Kertas(Origami) Di Raudhatul Athfal Ar-Russydah I Kedaton Bandar Lampung. Skripsi (Diterbitkan). Fakultas Tarbiyah Dan Keguruan Institut Agama Islam Negri Raden Intan Lampung. Http://Repository.Radenintan.Ac.Id/ 284/1/Skripsi_Gabungan.Pdf.(Diaks es Pada 26 Juli 2017)

Santrock, J.W. (2007) Psikologi Perkembangan Edisi II Jilid I. Jakarta: Erlangga

Yuli.I (2013). Meningkatkan Kemampuan Motorik Halus Anak Dengan Media Origami

Pada Kelompok A Di Tk Dharma Wanita Persatuan Tarik-Sidoarjo. http://jurnalmahasiswa.unesa.ac.id/a rticle/8979/19/article.pdf 